\title{
Evaluasi Kebijakan Pemerintah Daerah Provinsi Sulawesi Tenggara Terhadap Regulasi Penanganan Pandemi Corona Virus Disease 2019 Ditinjau dari Perspektif Hukum Kesehatan
}

\author{
An Evaluation of Government Policies in Southeast Sulawesi Provincial on \\ Regulation for Handling Corona Virus Disease 2019 Pandemic \\ from Health Law Perspective
}

\begin{abstract}
Juliwanto
Kantor Wilayah Kementerian Hukum dan Hak Asasi Manusia Sulawesi Tenggara E-mail: juli81wanto@gmail.com
\end{abstract}

\author{
Muhammad Jufri \\ Pascasarjana Universitas Halu Oleo \\ E-mail:muh.jufridewa@yahoo.com

\section{La Sensu} \\ Pascasarjana Universitas Halu Oleo \\ E-mail: lasensu_march72@yahoo.com
}

\begin{abstract}
The aims of this study are: To analyze the government basic policies of Southeast Sulawesi Provincial in dealing COVID-19 Pandemic; To analyze the implementation of regional government policies of Southeast Sulawesi Provincial during COVID-19 Pandemic; and To analyze the regulation of COVID-19 in regional government policies of Southeast Sulawesi Provincial from health protocol perspective. Methodology in used are law approach, conceptual approach, and case approach, meanwhile the research type in used are normative legal research and empirical legal research by examining primary data (laws and regulations, from 1945 Constitution of Republic Indonesia, Law Number 36 of 2019 concerning health, related laws and regulations and other policy). Results of the study show that the basis for regulatory the government of Southeast Sulawesi Provincial in handling the COVID-19 Pandemic is based on attribution of 1945 Constitution of Republic Indonesia Article 18 paragraph (6), and Authority based on Freies Ermessen to carry out the task of organizing public welfare, government is given the legal authority to interfere in activity carrying out the duties of public interest; 2). Government Policies in Southeast Sulawesi Provincial are the form of running the government in handling COVID-19 includes regulations, decisions, circulars, as well appeals. Type of this policy if it refers to the Regulation of National Archives Head Number 4 of 2014 concerning Guidelines for the Administration of Official Manuscripts, the appeal is not included in the guidelines for the
\end{abstract}


administration of official manuscripts; and 3). Government Policies in Southeast Sulawesi Provincial in handling COVID-19 Pandemic refers to the provision of health protocol.

Keyword: Evaluation; Policy; Pandemic Handling;

Abstrak: Penelitian ini bertujuan Menganalisis dasar kebijakan Pemerintah Daerah Provinsi Sulawesi Tenggara dalam menangani pandemi COVID-19; Menganalisis implementasi kebijakan pemerintah Daerah Provinsi Sulawesi Tenggara dimasa pandemi COVID-19; dan Menganalisis regulasi terkait COVID-19 Pemerintah Daerah Provinsi Sulawesi Tenggara dalam perspektif protokol kesehatan. penelitian ini menggunakan pendekatan undang-undang, pendekatan konseptual dan pendekatan kasus. penelitian ini menunjukkan: Bahwa dasar kewenangan pengaturan Pemerintah Daerah Provinsi Sulawesi Tenggara dalam penanganan pandemi COVID-19 berdasarkan atribusi UndangUndang Dasar Negara Republik Indonesia Tahun 1945 Pasal 18 ayat (6) dan Kewenangan berdasarkan Freies Ermessen; Kebijakan Pemerintah Provinsi Sulawesi Tenggara merupakan wujud menjalankan pemerintahan dalam rangka penanganan COVID-19 meliputi peraturan, keputusan, edaran, dan himbauan. Jenis kebijakan jika mengacu pada Peraturan Kepala Arsip Nasional Nomor 4 Tahun 2014 tentang Pedoman Tata Naskah Dinas, himbauan tidak termasuk dalam pedoman tata naskah dinas; dan Kebijakan Pemerintah Provinsi Sulawesi Tenggara dalam penanganan pandemi COVID-19 mengacu pada ketentuan protokol kesehatan.

Kata kunci: Evaluasi; Kebijakan; Penanganan Pandemi

\section{PENDAHULUAN}

Kesehatan merupakan modal utama dalam rangka pertumbuhan dan kehidupan bangsa dan mempunyai peranan penting dalam pembentukan masyarakat adil, makmur, dan sejahtera. Kesehatan merupakan salah satu unsur kesejahteraan umum harus diwujudkan sesuai dengan cita-cita bangsa Indonesia sebagaimana dalam Pembukaan Undang-Undang Dasar Negara Republik Indonesia Tahun 1945. Derajat kesehatan sangat berarti bagi pengembangan dan pembinaan sumber daya manusia sebagai salah satu modal bagi pelaksanaan pembangunan nasional yang pada hakikatnya adalah pembangunan manusia seutuhnya. ${ }^{1}$

Muhammad Jufri Dewa berpendapat bahwa Pemerintah dalam melakukan berbagai kegiatannya menggunakan instrumen hukum seperti peraturan, keputusan, peraturan kebijaksanaan, dan sebagainya. Sebagaimana dalam negara modern sekarang ini khususnya yang menganut type welfare state, pemberian kewenangan yang luas bagi pemerintah merupakan konsekuensi logis, termasuk memberikan kewenangan kepada pemerintah untuk menciptakan berbagai instrumen hukum sebagai sarana untuk kelancaran penyelenggaraan pemerintahan. Pembuatan instrumen hukum oleh pemerintah harus didasarkan pada

1 Maskawati, Andriani Misdar, Muji Iswanty, Hukum Kesehatan: Dimensi Etis dan Yuridis Tanggung Jawab Pelayan Kesehatan, Makassar: Litera, 2018, hlm. 1. 
ketentuan hukum yang berlaku atau didasarkan pada kewenangan yang diberikan oleh peraturan perundang-undangan. ${ }^{2}$

Kewenangan pemerintah daerah dalam penyelenggaraan publik yaitu berdasarkan asas legalitas yang merupakan salah satu prinsip utama yang menjadi dasar dalam penyelenggaraan pemerintahan dan kenegaraan yang berbasis hukum. Gagasan negara hukum menuntut agar penyelenggaraan kenegaraan dan pemerintahan kepada undang-undang dan memberikan jaminan terhadap hak dasar rakyat. ${ }^{3}$

Berkaitan dengan adanya pandemi COVID-19 yang disampaikan oleh Direktur Jenderal Organisasi Kesehatan Dunia Word Health Organization (WHO) Tedros Adhanom Ghebreyesus, Rabu, 11 Maret 2020. dalam konferensi persnya mengumumkan bahwa virus corona yang tengah merebak dan saat ini dikategorikan sebagai pandemi global. Pernyataan itu diumumkan. Penyebaran COVID-19 secara global berdampak pada berbagai aspek, baik kesehatan maupun ekonomi, sosial dan budaya. Indonesia adalah salah satu negara yang terdampak. Hal itu dapat dilihat dari data terakhir yang disampaikan gugus tugas COVID-19 per tanggal 30 Juli 2020 bahwa di Indonesia terdapat 104.432 yang terkonfirmasi positif COVID-19 yang tersebar di hampir seluruh wilayah Indonesia untuk menanggulangi penyebaran tersebut, Pemerintah melakukan berbagai upaya di antaranya dengan mengeluarkan berbagai produk peraturan perundang-undangan untuk merespons pandemi COVID-19 dan diterapkannya Pembatasan Sosial Berskala Besar (PSBB) di daerah yang tinggi angka penderita COVID-19.4

Beberapa peraturan perundang-undangan yang diterbitkan dengan adanya pandemi COVID-19 adalah: ${ }^{5}$

1. Peraturan Pemerintah Pengganti Undang-Undang Republik Indonesia Nomor 1 Tahun 2020 tentang Kebijakan Keuangan Negara dan Stabilitas Sistem Keuangan untuk Penanganan Pandemi COVID-19 dan/atau dalam Rangka Menghadapi Ancaman yang Membahayakan Perekonomian Nasional dan/atau Stabilitas Sistem Keuangan;

2. Peraturan Pemerintah Republik Indonesia Nomor 21 Tahun 2020 tentang Pembatasan Sosial Berskala Besar dalam Rangka Percepatan Penanganan COVID19;

3. Keputusan Presiden Republik Indonesia Nomor 11 Tahun 20209 tentang Penetapan Kedaruratan Kesehatan Masyarakat COVID-19;

2 Muh. Jufri Dewa, Hukum Administrasi Negara dalam Perspektif Pelayanan Publik, Kendari: Unhalu Press, 2011, hlm. 44-45.

3 Juniarso Ridwan, Achmad Sodik Sudrajat, Hukum Administrasi Negara dan Kebijakan Pelayanan Publik, Bandung: Nuansa Cendikia, 2009, hlm. 133-134.

4 Badan Pembinaan Hukum Nasional. Hukum Nasional di Era New Normal, Percikan Pemikiran Penyuluh Hukum. Jakarta: Pusat Dokumentasi dan Jaringan Informasi Hukum Nasional BPHN. 2020, hlm. i.

5 Ibid. 
4. Keputusan Presiden Republik Indonesia Nomor 12 Tahun 2020 tentang Penetapan Bencana Non Alam Penyebaran COVID-19 Sebagai Bencana Nasional;

5. Keputusan Presiden Nomor 7 Tahun 2020 tentang Gugus Tugas Percepatan Penanganan COVID-19 sebagaimana telah diubah dengan Keputusan Presiden Nomor 9 Tahun 2020 tentang Perubahan atas Keputusan Presiden Nomor 7 Tahun 2020 tentang Gugus Tugas Percepatan Penanganan COVID-19; dan

6. Peraturan Menteri Kesehatan Republik Indonesia Nomor 9 Tahun 2020 tentang Pedoman Pembatasan Sosial Berskala Besar dalam Rangka Percepatan Penanganan COVID-19.

Nando Marika Yussela menjelaskan "Surat edaran dapat di uji jika kita merujuk pada Undang-Undang Nomor 30 Tahun 2014 tentang Administrasi Pemerintahan Pasal 87 huruf a yaitu "penetapan tertulis yang juga mencakup tindakan faktual" dan huruf e yaitu "keputusan yang berpotensi menimbulkan akibat hukum". Dalam Peraturan Menteri Pendayagunaan Aparatur Negara dan Reformasi Birokrasi Republik Indonesia Nomor 80 Tahun 2012 dan Peraturan Kepala Arsip Nasional Republik Indonesia Nomor 2 Tahun 2014, surat edaran digolongkan sebagai produk tata naskah dinas oleh karena itu idealnya surat edaran hanya sebatas alat komunikasi kedinasan berupa pemberitahuan kepada kalangan internal dikarenakan sifatnya informatif maka surat edaran tidak boleh mengatur hal-hal yang melampaui kewenangan dan bertentangan dengan peraturan perundang-undangan. Selain itu juga dijelaskan oleh W. Riawan Tjandra "Hal yang penting untuk dicermati juga dalam upaya mengefektifkan langkah-langkah kebijakan pemerintah adalah pembentukan apa yang dalam Hukum Administrasi Negara disebut dengan peraturan kebijakan (policy rule). Peraturan Kebijakan bukanlah bagian dari hierarki peraturan perundang-undangan dalam ruang lingkup Undang-Undang Nomor 12 Tahun 2011 tentang Pembentukan Peraturan Perundangundangan. Peraturan Kebijakan dibentuk berdasarkan kewenangan diskresi pemerintah sebagai akibat adanya kebutuhan faktual dan operasional pemerintah dalam mengeksekusi sejumlah kebijakan penting, tetapi tidak ada perintah langsung dari undang-undang bagi pemerintah untuk membentuk peraturan pelaksanaan". ${ }^{6}$

Merespons pandemi COVID-19 pemerintah Provinsi Sulawesi Tenggara menjalankan fungsi pemerintahannya dengan mengeluarkan kebijakan-kebijakan dalam rangka mengendalikan COVID-19. Beberapa regulasi-regulasi yang telah dikeluarkan yaitu Surat Edaran Gubernur Sulawesi Tenggara No. 443/1715 Kepada Bupati/Walikota se-Sulawesi

\footnotetext{
6 "Kedudukan Surat Edaran Sebagai Produk Hukum dalam Penanggulangan COVID-19", Pusat Pengkajian Pancasila dan Konstitusi (PUSKAPSI) Fakultas Hukum Universitas Jember, http://puskapsi.fh.unej.ac.id/kedudukan-surat-edaran-sebagai-produk-hukum-dalam-penanggulangancovid-19/, diakses pada tanggal 8 Februari 2021.
} 
Tenggara tentang Pelaksanaan Ibadah Ramadhan dan Idul Fitri 1 Syawal $1441 \mathrm{H}$ dalam Keadaan Darurat Bencana Wabah COVID-19.

Kebijakan pemerintah dalam bentuk surat edaran ini ditanggapi beragam oleh masyarakat menjadi tidak konsisten dalam penanggulangan wabah virus corona seolah berlawanan dengan pernyataan Presiden bahwa bangsa Indonesia bisa tetap produktif sekaligus aman dari wabah penyakit infeksi itu. Di satu sisi pemerintah terus meminta masyarakat meningkatkan kedisiplinan dalam menjalankan protokol kesehatan, disisi lain banyak pernyataan dan kebijakan yang tidak konsisten, bahkan sejak awal terkesan meremehkan ancaman COVID-19. Publik menduga keinginan pemerintah memasuki New Normal berbasis kepentingan ekonomi. Dugaan ini wajar karena sejumlah aktivitas ekonomi yang dibatasi di era Pembatasan Sosial Berskala Besar (PSBB) bisa kembali beroperasi dengan New Normal, meski dengan protokol kesehatan yang ketat.7

Sehingga kajian surat edaran tersebut pada tindakan pemerintah sebagai bentuk diskresi dibutuhkan evaluasi terhadap Kebijakan Pemerintah Daerah Provinsi Sulawesi Tenggara dalam Penanganan Pandemi COVID-19 untuk membantu dalam pelaksanaan tugas sebagai pemenuhan kewenangan tetapi disisi lain memunculkan tindakan yang dapat menyalahgunakan kewenangan. dari uraian latar belakang masalah tersebut di atas, peneliti tertarik meneliti dengan judul "Evaluasi Kebijakan Pemerintah Daerah Provinsi Sulawesi Tenggara Terhadap Regulasi Penanganan Pandemi Corona Virus Disease 2019 Ditinjau dari Perspektif Hukum Kesehatan“.

\section{METODE PENELITIAN}

Penelitian hukum ini merupakan jenis penelitian hukum normatif empiris dengan mengkaji bahan-bahan hukum primer peraturan perundang-undangan (Undang-Undang Dasar Negara Republik Indonesia Tahun 1945, Undang-Undang Nomor 36 Tahun 2019 tentang Kesehatan, peraturan perundang-undangan terkait serta peraturan kebijakan lainnya). Penelitian hukum normatif merupakan penelitian hukum yang terdiri dari asas-asas hukum, penelitian terhadap sistematika hukum dan penelitian pada taraf sinkronisasi hukum, penelitian sejarah hukum dan penelitian mengenai perbandingan hukum. ${ }^{8}$ Objek yang dikaji melalui penelitian empiris berkaitan dengan pelaksanaan kebijakan pemerintah Provinsi Sulawesi Tenggara di tengah

\footnotetext{
7 Aldi Gultom, "Masih Amburadul Menuju New Normal?", AyoJakarta.com, https://www.ayojakarta.com/read/2020/05/29/18618/masih-amburadul-menuju-new-normal, diakses tanggal 23 Januari 2021.

8 Soerjono Soekanto, Pengantar Penelitian Hukum, Jakarta: RajaGrafindo Persada, 2014, hlm. 41-42.
} 
pandemi COVID-19 apakah telah terlaksana sesuai ketentuan peraturan perundang-undangan dan hukum kesehatan atau sebatas pelaksanaan formalitas. Selain itu, penelitian ini juga dilakukan dengan mengkaji bahan-bahan hukum sekunder berupa buku-buku, jurnal, hasil penelitian, dan karya ilmiah lainya. Penelitian ini juga bertujuan untuk mengumpulkan datadata primer berupa pemikiran-pemikiran beberapa pakar hukum tata negara yang diperoleh melalui metode kepustakaan.

\section{ANALISIS DAN PEMBAHASAN}

\section{Dasar Kebijakan Pemerintah Daerah Provinsi Sulawesi Tenggara dalam Penanganan Pandemi COVID-19}

Pemerintah daerah dalam menyelenggarakan pemerintahan tidak terlepas dari kewenangan, dalam konsep desentralisasi yang dianut negara Indonesia saat ini kewenangan pemerintah daerah berasal dari kewenangan yang diberikan oleh ketentuan peraturan perundangundangan yang berlaku. Dalam hukum positif pemberian kewenangan pemerintah daerah berasal dari Undang-Undang Dasar Negara Republik Indonesia Tahun 1945 dan Kewenangan Berdasarkan Freies Ermessen.

\section{Atribusi Undang-Undang Dasar Negara Republik Indonesia Tahun 1945}

Atribusi adalah pemberian Kewenangan kepada Badan dan/atau Pejabat Pemerintahan oleh Undang-Undang Dasar Negara Republik Indonesia Tahun 1945 atau Undang-Undang.9 Kewenangan pemerintah daerah dalam penyelenggaraan publik adalah berdasarkan asas legalitas yang merupakan salah satu prinsip utama yang menjadi dasar dalam penyelenggaraan pemerintahan dan kenegaraan yang berbasis hukum. Gagasan negara hukum menuntut agar penyelenggaraan kenegaraan dan pemerintahan kepada undang-undang dan memberikan jaminan terhadap hak dasar rakyat. ${ }^{10}$

Desentralisasi adalah merupakan penyerahan wewenang dari pemerintah pusat kepada pemerintah daerah untuk mengurus rumah tangganya sendiri. Namun penyerahan wewenang ini tidak diberikan secara penuh. Bentuk dari penggunaan asas desentralisasi adalah adanya otonomi daerah. Otonomi daerah merupakan sebuah kewenangan dimana suatu daerah memiliki tanggung jawab terhadap urusannya sendiri.11

9 Undang-Undang Republik Indonesia Nomor 30 Tahun 2014 tentang Administrasi Pemerintahan.

10 Juniarso Ridwan, Achmad Sodik Sudrajat, Loc. cit..

11 Syamsuddin Haris, Desentralisasi dan Otonomi Daerahlm. Jakarta: LIPPI Press, 2007, hlm. 52. 
Konsep desentralisasi menurut Brian C Smith menjelaskan desentralisasi pada masalah distribusi kekuasaan berdasarkan dimensi wilayah atau teritorial suatu negara. Smith menjelaskan bahwa konsep desentralisasi berkaitan dengan besaran pelimpahan kekuasaan (power) dan kewenangan (authoriy) yang diserahkan dari pemerintah pusat ke pemerintah lokal melalui hierarki secara geografis di negara. ${ }^{12}$

Pembagian kewenangan pemerintah daerah tertuang dalam konstitusi Negara Republik Indonesia yaitu dalam Undang-Undang Dasar Negara Republik Indonesia Tahun 1945 Bab VI dalam pasal 18 pada ayat (6) yang berbunyi "Pemerintahan daerah berhak menetapkan peraturan daerah dan peraturan-peraturan lain untuk melaksanakan otonomi dan tugas pembantuan". Secara teori kewenangan ini termasuk dalam kewenangan atribusi atau perintah langsung dari konstitusi Negara Indonesia atau Undang-Undang Dasar Negara Republik Indonesia Tahun 1945 berupa menetapkan peraturan daerah dan peraturan-peraturan lain atau peraturan kebijakan untuk melaksanakan otonomi dan tugas pembantuan lainya.

\section{Kewenangan Berdasarkan Freies Ermessen}

Menurut Ridwan HR. Freies berasal dari kata frei yang berarti bebas, lepas, tidak terikat dan merdeka. Freies artinya orang yang bebas, tidak terikat, dan merdeka. Sementara itu ermessen berarti mempertimbangkan, menilai, menduga, dan memperkirakan. Freies ermessen berarti orang yang memiliki kebebasan menilai, menduga, dan mempertimbangkan sesuatu. Istilah ini kemudian secara khusus digunakan di bidang pemerintahan, sehingga freies ermessen (diskresioner) diartikan sebagai salah satu sarana yang memberikan ruang gerak bagi pejabat atau badan-badan administrasi negara untuk melakukan tindakan tanpa terikat sepenuhnya pada Undang-Undang. 13

Untuk melaksanakan tugas menyelenggarakan kesejahteraan umum, pemerintah diberi kewenangan yang sah untuk turut campur dalam kegiatan melaksanakan tugas menyelenggarakan kepentingan umum. Kewenangan ini dikenal dengan istilah freies ermessen. Contoh freies ermessen: memberi izin, melakukan pencabutan hak (onteigening), mendirikan rumah sakit, sekolah, perusahaan, dan sebagainya. Dalam freies ermessen tercakup pula pengertian bahwa pemerintah dapat membuat peraturan tentang hal-hal yang belum ada

Brian C. Smith dalam Saiman, Politik Perbatasan. Malang: Inteligensia Media, 2017, hlm. 29.

13 Ibid, hlm. 20. 
pengaturannya, atau mengimplementasikan peraturan yang ada sesuai dengan kenyataan. Pengertian demikian disebut discretionary power. ${ }^{14}$

SF. Marbun dan Moh. Mahfud MD. Berpendapat meskipun pemerintah diberikan peluang untuk melaksanakan tugas pemerintahan secara bebas tanpa terikat sepenuhnya pada Undang-Undang, namun dalam kerangka negara hukum harus dipahami bahwa terdapat unsurunsur freies ermessen yang merupakan batasan bagi pemerintah, sebagai berikut: ${ }^{15} 1$. ditujukan untuk menjalankan tugas-tugas servis publik; 2. merupakan sikap tindak yang aktif dari administrasi negara; 3. sikap tindak itu dimungkinkan oleh hukum; 4. sikap tindak itu diambil atas inisiatif sendiri; dan 5. sikap tindak itu dimaksudkan untuk menyelesaikan persoalanpersoalan penting yang timbul secara tiba-tiba.

Ridwan HR. berpendapat untuk melaksanakan 3 (tiga) bentuk kewenangan berdasarkan freies ermessen pemerintah dilarang berbuat sewenang-wenang. Pemerintah dilarang melakukan tindakan-tindakan yang bersifat detournement de pouvoir (melakukan sesuatu di luar tujuan kewenangan yang diberikan) atau disebut juga onrechtmatige overheidsdaad (perbuatan melawan hukum oleh pemerintah). Sebab setiap perbuatan. pemerintah yang merugikan warganya karena detournement de powvoir atau onrechtmatige overheidsdaad dapat dituntut di muka hakim baik melalui peradilan administrasi negara maupun melalui peradilan umum. ${ }^{16}$

Berdasarkan Pasal 1 angka 9 Undang-Undang. Nomor 30 Tahun 2014 tentang Administrasi Pemerintahan, Diskresi diartikan sebagai Keputusan dan/atau Tindakan yang ditetapkan dan/atau dilakukan oleh Pejabat Pemerintahan untuk mengatasi persoalan konkret yang dihadapi dalam penyelenggaraan pemerintahan dalam hal Peraturan Perundangundangan yang memberikan pilihan, tidak mengatur, tidak lengkap atau tidak jelas, dan/atau adanya stagnasi pemerintahan. Diskresi hanya dapat dilakukan oleh Pejabat Pemerintahan yang berwenang. Setiap penggunaan Diskresi oleh Pejabat Pemerintahan bertujuan untuk: ${ }^{17}$ melancarkan penyelenggaraan pemerintahan; mengisi kekosongan hukum; memberikan kepastian hukum: dan mengatasi stagnasi pemerintahan dalam keadaan tertentu guna kemanfaatan dan kepentingan umum.

14 Nurillah Amini, Maidah Purwanti, Radita Adjie, Modul Pendidikan dan Pelatihan Fungsional Calon Pejabat Fungsional Perancang Peraturan Perundang-undangan: Peraturan Kebijakan (Legislasi Semu) dan Penetapan, Depok: Badan Pengembangan Sumber Daya Manusia Hukum dan HAM Kementerian Hukum dan Hak Asasi Manusia Republik Indonesia, 2016, hlm. 20.

15 Ibid, hlm. 21.

16 Ibid, hlm. 22.

17 Ibid. 


\section{Implementasi Kebijakan Pemerintah Daerah Provinsi Sulawesi Tenggara Dimasa Pandemi COVID-19}

\section{Kesiapan Hukum Nasional Menyongsong Era New Normal}

Status pandemi COVID-19 di Indonesia ditandai dengan terbitnya Keputusan Presiden Nomor 11 Tahun 2020 tentang Penetapan Kedaruratan Kesehatan Masyarakat COVID-19, yang selanjutnya dikuatkan dengan Keputusan Presiden Nomor 12 Tahun 2020 tentang Penetapan Bencana Non Alam Penyebaran COVID-19 sebagai Bencana Nasional yang dapat dikategorikan sebagai penyebab force majeure dalam kontrak pada umumnya. Hal ini kemudian ditindaklanjuti dengan Peraturan Pemerintah Pengganti Undang-Undang Nomor 1 Tahun 2020 tentang Kebijakan Keuangan Negara Dan Stabilitas Sistem Keuangan untuk Penanganan Pandemi COVID-19 dan/atau dalam Rangka Menghadapi Ancaman yang Membahayakan Perekonomian Nasional dan/atau Stabilitas Sistem Keuangan. ${ }^{18}$

Pemerintah Indonesia pasca pengumuman kasus positif virus COVID-19 pada tanggal 2 Maret 2020 terus meningkatkan upaya dan langkah-langkah untuk menekan penyebaran COVID-19, mulai dari membatasi hubungan sosial (social distancing), membatasi hubungan kontak fisik (physical distancing) sampai dengan himbauan seluruh aparatur negara, pegawai BUMN dan pegawai swasta untuk melakukan pembatasan aktivitas di kantor dengan menganjurkan untuk bekerja dari rumah work from home. ${ }^{19}$

Kebijakan Pemerintah yang terbaru dengan meminta "Masyarakat untuk berdamai dengan COVID-19 dengan mengumandangkan apa yang disebut New Normal atau pola hidup baru tentunya tidak terlepas dari upaya yang telah dilakukan oleh pemerintah selama ini dalam menangani penyebaran COVID-19. Pemberlakuan protokol kesehatan dengan pembatasan pergerakan masyarakat yang dilakukan oleh pemerintah berdampak langsung pada masyarakat tak terkecuali pada sektor pelayanan publik yang diselenggarakan oleh penyelenggara negara yang memberikan layanan langsung kepada masyarakat, pelayanan kesehatan di berbagai tingkatan fasilitas kesehatan, pelayanan keuangan pada sektor jasa perbankan dan lain-lain. Berdasarkan hasil Survei Indeks Persepsi Mal administrasi (Inperma) yang dilaksanakan oleh Ombudsman Republik Indonesia pada tahun 2019 menunjukkan 70.396 responden masih nyaman untuk mengurus secara langsung dibandingkan dengan mekanisme daring atau memakai jasa perantara. Adanya pembatasan-pembatasan yang

\footnotetext{
18 Badan Pembinaan Hukum Nasional, Perencanaan Pembangunan Hukum Nasional 2015-2019, Pusat Perencanaan Pembangunan Hukum Nasional, Jakarta: Pusat Perencanaan Pembangunan Hukum Nasional Badan Pembinaan Hukum Nasional Kementerian Hukum dan HAM RI, 2012. hlm. 10.

19 Ibid.
} 
dilakukan pemerintah menyebabkan pelayanan menjadi terhambat. Hal ini didasari bahwa kecenderungan masyarakat Indonesia untuk mengakses layanan publik secara langsung -masih sangat dominan sementara infrastruktur penunjang untuk pelayanan publik yang berbasis online masih belum optimal baik dari sisi penyelenggara negara maupun sosialisasi pada masyarakat terhadap akses layanan publik secara online. ${ }^{20}$

Negara sebagai pelayan masyarakat maka dengan menetapkan Kebijakan new normal dengan penerapan protokol kesehatan membuat akses pelayanan publik kepada masyarakat menjadi terbatas. Hal tersebut dapat dijadikan upaya bagi Negara dalam penyelenggaraan pelayanan publik sehingga memaksimalkan pemberian pelayanan publik.

\section{Sistem Hukum Nasional Pasca Pandemi COVID-19}

Sebagai negara hukum dalam rangka menerapkan new normal, Indonesia dalam hal ini pemerintah harus berpedoman dengan hukum nasional yang kita miliki. Sistem hukum nasional Indonesia sendiri merupakan hukum atau peraturan perundang-undangan yang dibentuk dan dilaksanakan untuk mencapai tujuan, dasar, dan cita hukum suatu negara. Dalam konteks ini hukum nasional Indonesia adalah kesatuan hukum atau peraturan perundang-undangan yang dibangun untuk mencapai tujuan negara yang bersumber pada Pancasila dan Undang-Undang Negara Republik Indonesia Tahun 1945. Dengan demikian, sistem hukum nasional Indonesia adalah sistem hukum yang berlaku di seluruh Indonesia yang meliputi semua unsur hukum seperti isi, struktur, budaya, sarana, peraturan perundang-undangan, dan semua sub unsurnya yang antara yang satu dengan yang lain saling bergantung. Sistem Hukum Nasional ini membentuk suatu kesatuan Interelasi antara politik hukum modern dan hukum tradisional yang mencerminkan budaya hukum komunal yang berdasarkan Pancasila. ${ }^{21}$

Hukum Nasional harus mampu menjawab permasalahan dalam menjalani penyesuaian yang perlu dilakukan di era new normal. Perubahan perilaku di era new normal ini adalah adanya kewajiban berupa penerapan protokol kesehatan serta adanya pembatasanpembatasan tertentu yang diterapkan pada masyarakat. Pelanggaran terhadap kewajiban dan larangan/pembatasan dapat dikenakan sanksi. Karena penyimpangan terhadap hukum tidak dapat dibenarkan dengan alasan pandemi COVID-19. Penegakan hukum harus tetap berjalan namun disesuaikan dengan keadaan new normal. Karena salah satu fungsi hukum adalah sarana

Ibid., hlm. 11.

21 Ibid., hlm. 18. 
mengubah masyarakat berdasarkan kepentingan masyarakat dan harus ditegakkan sebagai upaya sosial kontrol dalam rangka mencapai perubahan-perubahan yang dikehendaki. ${ }^{22}$

Berbagai perubahan perilaku seperti pengaturan terkait jaga jarak fisik hingga ketidakhadiran secara fisik, penerapan protokol kesehatan serta adanya beraneka pembatasan membuat masyarakat lebih mengutamakan teknologi komunikasi/digital sebagai jembatan penghubung antar individu. Diketemukan bahwa kehadiran secara fisik dalam berbagai peraturan perundang-undangan merupakan suatu keharusan, dan hal inilah yang menjadi pokok permasalahan dalam penerapan new normal. Dengan adanya keadaan new normal seperti sekarang ini diperlukan berbagai penyesuaian-penyesuaian perilaku dalam hukum kita. $^{23}$

Respons atas hal ini antara lain dapat dilihat dalam Pasal 5 ayat (1) UU No. 11 Tahun 2008 tentang Informasi dan Transaksi Elektronik, yang berkaitan dengan masalah kekuatan dalam sistem pembuktian dari Informasi, Dokumen, dan Tanda Tangan Elektronik menjawab permasalahan tersebut. Di mana secara umum dikatakan bahwa Informasi Elektronik dan/atau Dokumen Elektronik dan/atau hasil cetaknya merupakan alat bukti hukum yang sah, yang ? merupakan perluasan dari alat bukti yang sah sesuai dengan Hukum Acara yang berlaku di Indonesia. Demikian halnya dengan Tanda Tangan Elektronik, memiliki kekuatan hukum dan akibat hukum yang sah.

Di samping itu Pasal 5 ayat (1) sampai dengan ayat (3), secara tegas menyebutkan: Informasi Elektronik dan/atau Dokumen Elektronik dan/atau hasil cetaknya merupakan alat bukti hukum yang sah dan merupakan perluasan dari alat bukti yang sah sesuai dengan Hukum Acara yang berlaku di Indonesia. Namun dalam ayat (4) ada pengecualian yang menyebutkan Informasi Elektronik dan/atau Dokumen Elektronik tidak berlaku untuk: surat yang menurut Undang-Undang harus dibuat dalam bentuk tertulis; dan surat beserta dokumennya yang menurut Undang-Undang harus dibuat dalam bentuk akta notariil atau akta yang dibuat oleh pejabat pembuat akta. dari pengecualian tersebut terlihat bahwa belum semua peraturan mengakomodasi keadaan new normal ini, seperti terkait dengan Jabatan Notaris. ${ }^{24}$

dari pengecualian tersebut terlihat bahwa belum semua peraturan mengakomodasi keadaan new normal ini, seperti terkait dengan Jabatan Notaris. Seperti diketahui bahwa pekerjaan notaris banyak menggunakan teknologi. Untuk itu, dibutuhkan payung hukum agar

Ibid., hlm. 19.

23 Ibid.

24 Ibid., hlm. 20. 
tidak menjerat para notaris di kemudian hari. Jika tidak ada aturan jelas dikhawatirkan notaris bisa terjerat kasus hukum. Padahal sebagai pejabat umum, notaris harus dilindungi oleh aturan hukum.

Beberapa langkah telah dilakukan dengan lahirnya berbagai pengaturan di bawah Undang-Undang mengenai pelaksanaan penyelesaian permasalahan di masa pandemi. Sebagai contoh, Otoritas Jasa Keuangan mengeluarkan lima Peraturan sebagai tindak lanjut kewenangannya dalam pelaksanaan Peraturan Pemerintah Pengganti Undang-Undang Nomor 1 Tahun 2020 tentang Kebijakan Keuangan Negara dan Stabilitas Sistem Keuangan untuk Penanganan Pandemi COVID-19. Salah satu penyelesaian terhadap permasalahan hukum terkait kehadiran fisik adalah POJK Nomor 16/POJK.04/2020 tentang Pelaksanaan Rapat Umum Pemegang Saham Perusahaan Terbuka Secara Elektronik. Meski demikian pengaturan yang lebih tinggi, yaitu setingkat Undang-Undang sangat dibutuhkan untuk menjamin perlindungan dan kepastian hukum. ${ }^{25}$

Perlu dipahami bahwa keadaan new normal tidak boleh dijadikan alasan untuk menyimpang/melanggar hukum yang berlaku melainkan hukum tetap ditegakkan namun penegakan hukum/sanksi pidana dapat diselaraskan dengan keadaan new normal. Seperti halnya pidana baik denda/kurungan dapat digantikan dengan kerja sosial berdasarkan protokol kesehatan, contoh seperti ini sudah dilakukan pada pelanggar Pembatasan Sosial Berskala Besar yang tidak memakai masker diberikan sanksi untuk melakukan pekerjaan bersih-bersih, diskresi dijalankan dalam hal ini. Diharapkan perubahan perilaku di era new normal adalah dapat ditegakkannya sistem hukum yang bertujuan (utama) menciptakan perdamaian (justice for peace) di dalam kehidupan masyarakat sesuai dengan Pancasila yang kita miliki. ${ }^{26}$

\section{Jenis Kebijakan Pemerintah Provinsi Sulawesi Tenggara dalam Penanganan Pandemi COVID-19}

Di dalam penyelenggaraan tugas-tugas administrasi negara, pemerintah banyak mengeluarkan kebijaksanaan yang dituangkan dalam berbagai bentuk seperti beleidslijnen (garis-garis kebijaksanaan), het beleid (kebijaksanaan), voorschriften (peraturan-peraturan), richtlijnen (pedoman-pedoman), regelingen (petunjuk-petunjuk), circulaires (surat edaran), resoluties (resolusi-resolusi), aanschrijvingen (instruksi-instruksi), beleidsnota's (nota kebijaksanaan),

\footnotetext{
Ibid.

26 Ibid., hlm. 21.
} 
reglemen (ministriele) (peraturan-peraturan menteri), beschikkingen (keputusan-keputusan), en bekenmakingen (pengumuman-pengumuman). ${ }^{27}$

Jenis naskah dinas sesuai ketentuan peraturan perundang-undangan terdiri atas: ${ }^{28}$ a. Naskah Dinas Arahan yang meliputi: 1) Naskah dinas pengaturan yang terdiri atas (Peraturan, Pedoman, Petunjuk pelaksanaan/petunjuk teknis, Instruksi, Standar Operasional Prosedur (SOP), dan Surat edaran). 2). Naskah dinas penetapan (keputusan); dan 3). Naskah dinas penugasan (surat perintah/surat tugas). b. Naskah Dinas Korespondensi yang meliputi: 1). Naskah dinas korespondensi intern yang terdiri atas (nota dinas; dan disposisi); dan 2). Naskah dinas korespondensi ekstern. c. Naskah Dinas Khusus terdiri atas: 1). surat perjanjian (Perjanjian dalam negeri dan Perjanjian internasional); 2). Surat kuasa; 3). Berita acara; 4). Surat keterangan; 5). Surat pengantar; dan Pengumuman. d. Laporan, dan e. Telaah staf.

dari teori yang dikemukakan oleh J.H. Van Kreveld, Indroharto tersebut, dan berdasarkan Peraturan Kepala Arsip Nasional Republik Indonesia Nomor 2 Tahun 2014 tentang Pedoman Tata Naskah Dinas di atas Pemerintah Daerah Provinsi Sulawesi Tenggara sesuai kewenangan yang diberikan dalam penyelenggaraan pemerintahan mengeluarkan Instrumen regulasi untuk penanggulangan pandemi COVID-19 berupa: 1. Peraturan berjumlah 1 (satu) naskah; 2. Keputusan berjumlah 9 (sembilan) naskah; 3. edaran berjumlah 6 (enam) naskah; dan 4. Himbauan berjumlah 3 (tiga) naskah. Jenis himbauan jika mengacu pada ketentuan peraturan perundang-undangan ataupun teori-teori yang ada, tidak termasuk dalam jenis naskah dinas sebagaimana dimaksud pada Peraturan Kepala Arsip Nasional Republik Indonesia Nomor 2 Tahun 2014 tentang Pedoman Tata Naskah Dinas ataupun teori para ahli.

\section{Sanksi dan Pelaksanaan pada Kebijakan Pemerintah Daerah Provinsi Sulawesi Tenggara}

A. Hamid S Attamimi menjelaskan bahwa materi muatan peraturan kebijakan mengandung materi muatan yang berhubungan dengan kewenangan membentuk keputusan-keputusan dalam arti beschikkingen, kewenangan bertindak dalam bidang hukum privat, dan kewenangan membuat rencana-rencana yang memang ada pada lembaga pemerintahan. Sementara itu, materi muatan peraturan perundang-undangan mengatur tata kehidupan masyarakat yang

27 Sjahran Basah, Menelaah Lika-Liku Rancangan Undang-undang No. .5 Tahun 1986 tentang Peradilan Tata Usaha Negara, Bandung: Alumni, 1992, hlm. 4-5. Lihat juga di Mohammad Yuhdi, "Peranan Diskresi dalam Penyelenggaraan Pemerintahan", Likhitaprajna: Jurnal Ilmiah Fakultas Keguruan Ilmu Pendidikan Universitas Wisnuwardhana, Volume. 15, Nomor 1. 2013, hlm. 72.

28 Lampiran Peraturan Kepala Arsip Nasional Republik Indonesia Nomor 2 Tahun 2014 tentang Pedoman Tata Naskah Dinas, hlm. 1. 
jauh lebih mendasar, seperti mengadakan suruhan dan larangan untuk berbuat atau tidak berbuat, yang apabila perlu disertai dengan sanksi pidana dan sanksi perdata. Pembentukan peraturan perundang-undangan merupakan fungsi negara. Pembentukan hukum melalui perundang-undangan dilakukan oleh rakyat, wakil rakyat, atau sekurang-kurangnya dengan persetujuan wakil rakyat. Kekuasaan dibidang perundang-undangan (kekuasaan legislatif) hanya diberikan kepada lembaga yang khusus, yaitu lembaga legislatif (organ kenegaraan yang bertindak untuk dan atas nama negara). ${ }^{29}$

Sanksi dalam penanganan pandemi COVID-19 oleh Pemerintah Daerah Provinsi Sulawesi Tenggara dapat dilihat dalam Bab IV Pasal 7 Peraturan Gubernur Sulawesi Tenggara Nomor 29 Tahun 2020 tentang Pedoman Penerapan Disiplin dan Penegakan Hukum Protokol Kesehatan Pencegahan dan Pengendalian Corona Virus Disease 2019. Sanksi dalam kebijakan tersebut meliputi:

(1) Bagi perorangan, pelaku usaha, pengelola, penyelenggara atau penanggung jawab tempat dan fasilitas tempat umum yang melanggar kewajiban sebagaimana dimaksud dalam pasal 4 dikenakan sanksi.

(2) Sanksi pelanggaran penerapan protokol kesehatan dalam pencegahan dan pengendalian COVID-19 sebagaimana dimaksud pada ayat (1) berupa:

a. bagi perorangan:

1) teguran lisan;

2) kerja sosial antara lain membersihkan tempat fasilitas umum sebagaimana dimaksud pada Pasal 5, sesingkat-singkatnya 30 (tiga puluh) menit,

3) denda administratif sekurang-kurangnya Rp. 50.000,(lima puluh ribu) dan setinggi-tingginya Rp. 200.000,(dua ratus ribu rupiah).

b. bagi pelaku usaha, pengelola, penyelenggara, atau penanggung jawab tempat, dan fasilitas umum:

1) teguran lisan atau teguran tertulis;

2) denda administratif sekurang-kurangnya Rp. 50.000, (lima puluh ribu) dan setinggi-tingginya Rp. 500.000, (lima ratus ribu rupiah).

3) penghentian sementara operasional usaha; dan

4) pencabutan izin usaha.

(3) Dalam pelaksanaan, penerapan sanksi sebagaimana dimaksud pada ayat (2) berkoordinasi dengan Instansi/Lembaga terkait, Tentara Nasional Indonesia, dan Kepolisian Negara Republik Indonesia dan Ketua Gugus Tugas Daerah.

Dalam wawancara dengan anggota Satuan Gugus Tugas COVID-19 a.n. Ade Suhartono tanggal 24 Mei 2021 bahwa selama ini dalam melaksanakan operasi yustisi Satgas COVID-19 tidak memberlakukan sanksi baik perseorangan maupun subjek hukum lainya sebagaimana dimaksud dalam Pasal 7 ayat (1) sampai dengan ayat (3) namun hanya melakukan edukasi

29 Hamid S Attamimi, Hukum tentang Peraturan Perundang-undangan dan Peraturan Kebijakan, Pidato Purnabakti, Jakarta: Fakultas Hukum UI, 20 September 1993, hlm. 12-13. 
kepada masyarakat berupa mengingatkan pentingnya menerapkan protokol kesehatan dan memberikan masker bagi masyarakat yang tidak mengenakan dengan alasan bahwa tidak ada dasar hukum jika dalam penerapan sanksi bagi masyarakat yang melanggar protokol kesehatan. Hal senada disampaikan oleh La Ode Zulkifli B., S.H. Kasubbag Penyusunan Produk Hukum Pengaturan Biro Hukum Sekretariat Daerah Provinsi Sulawesi Tenggara dalam wawancara tanggal 29 April 2020 bahwa selama pandemi kebijakan yang dikeluarkan tidak mengatur sanksi sehingga tidak mengakibatkan efek jera. Lebih lanjut beliau mengatakan bahwa dalam pemberian sanksi perlu adanya kajian ilmiah karena dimasa pandemi ini kondisi ekonomi tidak stabil dan baiknya diterapkan dalam bentuk Peraturan Daerah karena melalui kajian yang komprehensif serta mempunyai legitimasi yang kuat.

\section{Urgensi Pembentukan Peraturan Daerah dalam Penanganan Pandemi COVID-19}

Peristiwa yang muncul sebagai bentuk respons salah satu di antaranya melalui demonstrasi masyarakat Sulawesi Tenggara terhadap kebijakan yang dikeluarkan Pemerintah Daerah Provinsi Sulawesi Tenggara dalam penanganan pandemi COVID-19 dimungkinkan karena ketentuan dalam membentuk peraturan kebijakan berbeda dengan ketentuan dalam pembentukan peraturan perundang-undangan.

Ketentuan dalam pembentukan peraturan perundang-undangan harus dilakukan berdasarkan pada asas pembentukan peraturan perundang-undangan yang baik, yang meliputi: ${ }^{30}$ kejelasan tujuan; kelembagaan atau pejabat pembentuk yang tepat; kesesuaian antara jenis, hierarki, dan materi muatan; dapat dilaksanakan; kedayagunaan dan kehasilgunaan; kejelasan rumusan; dan keterbukaan.

Asas materi muatan dalam peraturan perundang-undangan harus mencerminkan: ${ }^{31}$ pengayoman; kemanusiaan; kebangsaan; kekeluargaan; kenusantaraan; bhinneka tunggal ika; keadilan; kesamaan kedudukan dalam hukum dan pemerintahan; ketertiban dan kepastian hukum; dan/atau keseimbangan, keserasian, dan keselarasan.

Dalam pembentukan peraturan perundang-undangan partisipasi masyarakat dibutuhkan, sesuai ketentuan bahwa:32 Masyarakat berhak memberikan masukan secara lisan dan/atau tertulis dalam Pembentukan Peraturan Perundang-undangan; dan Masukan secara

\footnotetext{
30 Undang-Undang Republik Indonesia Nomor 12 Tahun 2011 tentang Pembentukan Peraturan Perundangundangan, hlm. 5.

31 Ibid.

32 Ibid., hlm. 47.
} 
lisan dan/atau tertulis dapat dilakukan melalui: rapat dengar pendapat umum; kunjungan kerja; sosialisasi; dan/atau seminar, lokakarya, dan/atau diskusi.

Proses pembentukan peraturan daerah dibentuk oleh lembaga Dewan Perwakilan Rakyat Daerah Provinsi dengan persetujuan bersama Gubernur berbeda halnya dengan pembentukan peraturan kebijakan yang merupakan perluasan diskresioner pemerintah daerah hanya dibentuk oleh organ pemerintah daerah Provinsi Sulawesi Tenggara. ${ }^{33}$ Pasal 57 ayat (1) menyebutkan bahwa Penyusunan Naskah Akademik Rancangan Peraturan Daerah Provinsi dilakukan sesuai dengan teknik penyusunan Naskah Akademik. ${ }^{34}$ Naskah Akademik adalah naskah hasil penelitian atau pengkajian hukum dan hasil penelitian lainnya terhadap suatu masalah tertentu yang dapat dipertanggungjawabkan secara ilmiah mengenai pengaturan masalah tersebut dalam suatu Rancangan Undang-Undang, Rancangan Peraturan Daerah Provinsi, Rancangan Peraturan Daerah Kabupaten/Kota, sebagai solusi terhadap permasalahan dan kebutuhan hukum masyarakat. 35

Beberapa ketentuan dalam pembentukan peraturan perundang-undangan tersebut di atas dimaksudkan agar tujuan mewujudkan Indonesia sebagai negara hukum, melaksanakan pembangunan hukum nasional yang dilakukan secara terencana, terpadu, dan berkelanjutan dalam sistem hukum nasional yang menjamin pelindungan hak dan kewajiban segenap rakyat Indonesia berdasarkan Undang-Undang Dasar Negara Republik Indonesia Tahun 1945 dapat diwujudkan. Dengan demikian regulasi penanganan COVID-19 di Provinsi Sulawesi Tenggara sebaiknya ditingkatkan dalam bentuk peraturan daerah karena melalui tahapan pembentukan yang komprehensif.

\section{Protokol Kesehatan Kebijakan Penanganan Pandemi COVID-19 Pemerintah Daerah Provinsi Sulawesi Tenggara}

Menurut teori campuran, isi hukum harus ditentukan menurut dua asas, yaitu keadilan dan kemanfaatan. Dalam hal ini, menurut van Kant bahwa hukum bertujuan menjaga kepentingan tiap manusia agar kepentingan itu tidak terganggu. Hukum mengandung suatu pertimbangan menentukan kepentingan mana lebih besar dari pada yang lain. ${ }^{36}$ Melalui kebijakan Pemerintah Daerah Provinsi Sulawesi Tenggara dalam penanganan pandemi COVID-19 adalah dalam

33 Ibid., hlm. 3.

34 Ibid., hlm. 4.

35 Lampiran I Undang-Undang Republik Indonesia Nomor 12 Tahun 2011 tentang Pembentukan Peraturan Perundang-undangan, hlm. 1.

36 Maskawati, Andriani Misdar, Muji Iswanti, Op. cit., hlm. 2. 
rangka pertimbangan besar yaitu kepentingan terhadap masyarakat Sulawesi Tenggara agar dapat terpenuhi hak-haknya selama pandemi COVID-19 baik bagi yang terpapar maupun bagi yang tidak terpapar agar terhindar dari COVID-19.

Selama pandemi COVID-19 kebijakan yang diterbitkan Pemerintah Daerah Provinsi Sulawesi Tenggara sebagai langkah-langkah dalam penanganan pandemi dapat dilihat melalui regulasi-regulasi yang diterbitkan dalam rangka memenuhi kepastian dan tanggung jawab kepada masyarakat dan dapat dilihat dalam penahapannya melalui keputusan-keputusan sebagai langkah strategis penanganan COVID-19 yang meliputi:

\section{Pengorganisasian}

Pengorganisasian dalam keadaan penanggulangan krisis kesehatan diatur dalam Peraturan Menteri Kesehatan Republik Indonesia Nomor 75 Tahun 2019 tentang Penanggulangan Krisis Kesehatan pada Bab II dalam Pasal 4 ayat (1) menyebutkan bahwa Penanggulangan Krisis Kesehatan dilakukan dengan sistem klaster. Kemudian pada ayat (2) menyebutkan Sistem klaster diimplementasikan melalui pembentukan Klaster Kesehatan pada tingkat pusat dan tingkat daerah yang bertujuan untuk meningkatkan koordinasi, kolaborasi, dan integrasi dalam Penanggulangan Krisis Kesehatan.

Dengan demikian bahwa pembentukan klaster merupakan tahapan pengorganisasian berdasarkan ketentuan dalam Peraturan Menteri Kesehatan Republik Indonesia Nomor 75 Tahun 2019 tentang Penanggulangan krisis kesehatan tersebut. Adapun organisasi yang dibentuk melalui keputusan gubernur dalam penanganan pandemi COVID-19 meliputi: Pembentukan Gugus Tugas Percepatan Penanganan COVID-19, Pembentukan Kelompok Kerja Pencegahan Penularan COVID-19.

\section{Penetapan Rumah Sakit Rujukan COVID-19}

Kebijakan pemerintah daerah Provinsi Sulawesi Tenggara dalam rangka penanganan pandemi COVID-19 meliputi: 1). penetapan rumah sakit umum rujukan COVID-19 melalui Keputusan Gubernur Sulawesi Tenggara Nomor 202 Tahun 2020 Penetapan Rumah Sakit Umum Rujukan COVID-19; 2). Keputusan Gubernur Sulawesi Tenggara Nomor 229 Tahun 2020 Penetapan Rumah Sakit Jiwa Provinsi Sultra Sebagai Tempat Penanganan Pasien Corona tanggal 30 Maret 2020.

Jika mengacu pada ketentuan yang ada bahwa penetapan rumah sakit rujukan oleh Pemerintah Daerah Provinsi Sulawesi Tenggara dalam penanganan COVID-19 telah sesuai 
dengan Undang-Undang Republik Indonesia Nomor 44 Tahun 2009 tentang Rumah Sakit, dalam Pasal 24 ayat (1) menyebutkan bahwa dalam rangka penyelenggaraan pelayanan kesehatan secara berjenjang dan fungsi rujukan, rumah sakit umum dan rumah sakit khusus diklasifikasikan berdasarkan fasilitas dan kemampuan pelayanan Rumah Sakit. Dalam rangka penanganan pandemi COVID-19 Pemerintah Daerah Provinsi Sulawesi Tenggara telah menetapkan rumah sakit rujukan berdasarkan klasifikasi sebagaimana dimaksud dalam Pasal 24 ayat(1) Undang-Undang Nomor 44 Tahun 2009 tentang Rumah Sakit.

\section{Pengelolaan Anggaran COVID-19}

Sesuai ketentuan Undang-Undang Republik Indonesia Nomor 24 Tahun 2007 tentang Penanggulangan Bencana Pasal 61 ayat (2) bahwa Penggunaan anggaran penanggulangan bencana yang memadai dilaksanakan oleh Pemerintah, pemerintah daerah, badan nasional penanggulangan bencana dan badan penanggulangan bencana daerah sesuai dengan tugas pokok dan fungsinya.

Dengan kewenangan yang diberikan tersebut pengelolaan anggaran Pemerintah Daerah Provinsi Sulawesi Tenggara mengeluarkan kebijakan melalui beberapa keputusan gubernur di antaranya: 37 1). Keputusan tentang Penetapan Satker Pengelola Dana Tak Terduga COVID-19; 2). Keputusan tentang Pembentukan Tim Anggaran Pemerintah Daerah tentang Penyusunan Revisi Anggaran Re-Focusing COVID-19; 3). Keputusan tentang Penetapan Penerima Honor Tim Gugus Tugas Percepatan Penanganan Corona Virus Disease (COVID-19), dan 4). Keputusan tentang Penetapan Daftar Nama-nama Masyarakat Miskin Penerima Bantuan Beras Berdampak Corona.

\section{KESIMPULAN}

Berdasarkan uraian dari analisis pada tiap bab, dapat ditarik kesimpulan sebagai jawaban terhadap permasalahan yang diajukan sebagai berikut: 1). Dasar kewenangan pemerintah daerah Provinsi Sulawesi Tenggara dalam membuat kebijakan penanganan pandemi COVID-19 mengacu pada ketentuan Undang-Undang Dasar Negara Republik Indonesia Tahun 1945 Pasal 18 ayat (6), dan Kewenangan berdasarkan Freies Ermessen untuk melaksanakan tugas menyelenggarakan kesejahteraan umum yaitu pemerintah diberi kewenangan yang sah untuk turut campur dalam kegiatan melaksanakan tugas menyelenggarakan kepentingan umum; 2).

37 Biro Hukum Sekretariat Daerah Provinsi Sulawesi Tenggara. 
Implementasi kebijakan Pemerintah Provinsi Sulawesi Tenggara dalam rangka penanganan COVID-19 meliputi: peraturan, keputusan, edaran, dan himbauan. Dalam penerapan kebijakan belum efektif sanksi yang termuat dalam kebijakan belum bisa diterapkan, mengingat belum adanya legitimasi hukum yang kuat dalam kebijakan-kebijakan penanganan pandemi COVID19. 3). Regulasi Pemerintah daerah Provinsi Sulawesi Tenggara dalam rangka penanganan pandemi COVID-19 berdasarkan protokol kesehatan mengacu pada materi muatan dalam Undang-Undang Republik Indonesia Nomor 24 Tahun 2007 tentang Penanggulangan Bencana, Undang-Undang Republik Indonesia Nomor 44 Tahun 2009 tentang Rumah Sakit, dan Peraturan Menteri Kesehatan Republik Indonesia Nomor 75 Tahun 2019 tentang Penanggulangan Krisis Kesehatan.

\section{Daftar Pustaka}

\section{Buku}

Amini, Nurillah, Maidah Purwanti, Radita Adjie, Modul Pendidikan dan Pelatihan Fungsional Calon Pejabat Fungsional Perancang Peraturan Perundang-undangan: Peraturan Kebijakan (Legislasi Semu) dan Penetapan, Depok: Badan Pengembangan Sumber Daya Manusia Hukum dan HAM Kementerian Hukum dan Hak Asasi Manusia Republik Indonesia, 2016.

Badan Pembinaan Hukum Nasional, Perencanaan Pembangunan Hukum Nasional 2015-2019,

Pusat Perencanaan Pembangunan Hukum Nasional, Jakarta: Pusat Perencanaan Pembangunan Hukum Nasional Badan Pembinaan Hukum Nasional Kementerian Hukum dan HAM RI, 2012.

Badan Pembinaan Hukum Nasional. Hukum Nasional di Era New Normal, Percikan Pemikiran Penyuluh Hukum. Jakarta: Pusat Dokumentasi dan Jaringan Informasi Hukum Nasional BPHN. 2020.

Basah, Sjahran, Menelaah Lika-Liku Rancangan Undang-undang No. .5 Tahun 1986 tentang Peradilan Tata Usaha Negara, Bandung: Alumni, 1992.

Dewa, Muh. Jufri, Hukum Administrasi Negara dalam Perspektif Pelayanan Publik, Kendari: Unhalu Press, 2011.

Haris, Syamsuddin, Desentralisasi dan Otonomi Daerahlm. Jakarta: LIPPI Press, 2007.

Maskawati, Andriani Misdar, Muji Iswanty, Hukum Kesehatan: Dimensi Etis dan Yuridis Tanggung Jawab Pelayan Kesehatan, Makassar: Litera, 2018. 
Ridwan, Juniarso, Achmad Sodik Sudrajat, Hukum Administrasi Negara dan Kebijakan Pelayanan Publik, Bandung: Nuansa Cendikia, 2009.

Saiman, Politik Perbatasan. Malang: Inteligensia Media, 2017.

Soekanto, Soerjono, Pengantar Penelitian Hukum, Jakarta: RajaGrafindo Persada, 2014.

\section{Jurnal dan Makalah}

Attamimi, Hamid S, Hukum tentang Peraturan Perundang-undangan dan Peraturan Kebijakan, Pidato Purnabakti, Jakarta: Fakultas Hukum UI, 20 September 1993.

Yuhdi, Mohammad, “Peranan Diskresi dalam Penyelenggaraan Pemerintahan", Likhitaprajna: Jurnal Ilmiah Fakultas Keguruan Ilmu Pendidikan Universitas Wisnuwardhana, Volume. 15, Nomor 1. 2013.

\section{Peraturan Perundang-undangan}

Undang-Undang Republik Indonesia Nomor 12 Tahun 2011 tentang Pembentukan Peraturan Perundang-undangan.

Undang-Undang Republik Indonesia Nomor 30 Tahun 2014 tentang Administrasi Pemerintahan.

Peraturan Kepala Arsip Nasional Republik Indonesia Nomor 2 Tahun 2014 tentang Pedoman Tata Naskah Dinas.

\section{Situs Web}

“Kedudukan Surat Edaran Sebagai Produk Hukum dalam Penanggulangan COVID-19”, Pusat Pengkajian Pancasila dan Konstitusi (PUSKAPSI) Fakultas Hukum Universitas Jember, http://puskapsi.fh.unej.ac.id/kedudukan-surat-edaran-sebagai-produk-hukum-dalampenanggulangan-covid-19/, diakses pada tanggal 8 Februari 2021.

Gultom, Aldi, "Masih Amburadul Menuju New Normal?", AyoJakarta.com, https://www.ayojakarta.com/read/2020/05/29/18618/masih-amburadul-menujunew-normal, diakses tanggal 23 Januari 2021. 